\title{
New names for three African Acanthaceae
}

\author{
Kaj Vollesen ${ }^{1}$ \& lain Darbyshire ${ }^{1}$ (D)
}

Summary. Four nomenclatural errors in African Acanthaceae are corrected, resulting in the publication of one new combination in Duosperma, D. kaessneri (S. Moore) Vollesen \& I. Darbysh., two new names in Justicia, J. plectranthoides Vollesen \& I. Darbysh. and J. subcordatifolia Vollesen \& I. Darbysh., and a correction of the author combination for Dicliptera cernua.

Key Words. Flora of Tropical East Africa, Flora Zambesiaca, Lepidagathis, Peristrophe, taxonomy.

\section{Introduction}

The accounts of the Acanthaceae for the Flora of Tropical East Africa (Vollesen 2008; Darbyshire et al. 2010) and Flora Zambesiaca (Vollesen 2013; Darbyshire et al. 2015) documented 598 species and 401 species respectively, totalling 788 species across the two regions. This included the description of 193 new taxa (over $20 \%$ of the total Acanthaceae diversity) and 48 new combinations or new names for taxa in the two Flora regions, published either within the Flora volumes themselves or through various taxonomic papers and generic revisions that were written in preparation for the Flora accounts, such as the monograph of the genus Duosperma Dayton (Vollesen 2006). Since the publication of these Flora volumes and related taxonomic works, four nomenclatural errors or oversights have been brought to the attention of the authors and these are corrected below, resulting in the publication of one new combination, two new names and one corrected author combination.

\section{The identity of Lepidagathis kaessneri S. Moore} During examination of material at the Natural History Museum, London (BM) in connection with the preparation of an account of Lepidagathis Willd. for Flora of Tropical East Africa, one of the authors (I. D.) studied the type specimen of L. kaessneri S. Moore and discovered that it was not a Lepidagathis. Subsequent examination at the Kew herbarium $(\mathrm{K})$ of the type specimen showed that this is clearly a species of Duosperma Dayton. Perusal of the recent monograph of Duosperma (Vollesen 2006) and the collections at K quickly established that L. kaessneri is identical with D. longebracteolatum, a species described by Vollesen in that paper. Lepidagathis is systematically so far removed from Duosperma that it was never considered necessary to examine species from this genus in connection with the monographic work on Duosperma. A new combination is thus necessary.

Duosperma kaessneri (S. Moore) Vollesen $\mathcal{E}$ I. Darbysh. comb. nov. Type: Democratic Republic of the Congo, Katanga Region, Kundelungu, 15 May 1908, Kässner 2774 (holotype BM; isotype MO).

http://www.ipni.org/urn:lsid:ipni.org:names:60476869-2

Lepidagathis kaessneri S. Moore, J. Bot. 47: 294 (1909); Lebrun \& Stork (1997: 493).

Duosperma longebracteolatum Vollesen (2006: 313). Type: Democratic Republic of the Congo, Katanga Region, Kinika, 22 June 1957, Duvigneaud 3636 (holotype BRLU), synon. nov.

Justicia plectranthoides Vollesen \& I. Darbysh., a new name for Justicia interrupta (Lindau) C. B. Clarke

Justicia interrupta Kunth (1818: 232) — type: Colombia, Santa Ana, Sept. 1801, Bonpland E Humboldt s.n. (holotype P) — is a little known species which has been largely overlooked since its publication. For the account of Acanthaceae for Flora of Tropical East Africa, Vollesen (2010: 525) followed the concept of C. B. Clarke (in Burkill \& Clarke 1900: 207) for Justicia interrupta and overlooked the much earlier name. A new name is thus needed for the fairly widespread and very characteristic Tanzanian coastal forest species with its large, resupinate corolla. This resupination, an uncommon occurrence in Justicia $\mathrm{L}$. is caused by the pedicel bending backwards (Vollesen 2010). We thank Matthew Cock, Chief Scientist at the Centre for Agriculture and Biosciences International (CABI), for first alerting us to this oversight.

\footnotetext{
Accepted for publication 14 August 2018. Published online 1 October 2018

1 Identification \& Naming Department, Royal Botanic Gardens, Kew, Richmond, Surrey, TW9 3AB, UK. e-mail: k.vollesen@kew.org
} 
Justicia plectranthoides Vollesen $\mathcal{E} I$. Darbysh. nom. nov.

http://www.ipni.org/urn:lsid:ipni.org:names:60476870-2

Justicia interrupta (Lindau) C. B. Clarke, Fl. Trop. Afr. 5: 207 (in Burkill \& Clarke 1900) nom. illegit., non Justicia interrupta Kunth (1818: 232). Type: Tanzania, Pangani Distr., Potwe Forest, 29 Dec. 1960, Semsei 3138 (neotype K, chosen by Vollesen [2010]; isoneotypes BR, EA).

Duvernoia interrupta Lindau (1895: 123).

\section{Justicia subcordatifolia Vollesen \& I. Darbysh., a} new name for Justicia hedrenii Vollesen

Justicia hedrenii Vollesen (2015: 201) is a later homonym of J. hedrenii J.-P. Lebrun \& Stork (in Lebrun et al. 1991: 233). When naming his J. hedrenii in the account of Justicia for Flora Zambasiaca, Vollesen (2015) overlooked the identically named, recently described species from Chad. A new name is therefore needed for this species.

Justicia subcordatifolia Vollesen $\mathcal{E} \mathcal{V}^{\mathrm{I}}$. Darbysh., nom. nov.

http://www.ipni.org/urn:lsid:ipni.org:names:77187916-1

Justicia hedrenii Vollesen, Flora Zambesiaca. Vol. 8 (6): 201 (2015) nom. illegit., non Justicia hedrenii J.-P. Lebrun \& Stork (in Lebrun et al. 1991: 233). Type: Zimbabwe, Mutare Distr., Mutaranpanda, 4 Feb. 1956, Chase 5993 (holotype K; isotypes BM, SRGH).

\section{The correct author combination for Dicliptera cernua}

Based on morphological evidence, Darbyshire \& Vollesen (2007) broadened the concept of the genus Dicliptera Juss. to include species formerly placed in Peristrophe Nees, a decision that is supported by recently published molecular phylogenetic data on the "justicioid" lineage of Acanthaceae (Kiel et al. 2017). However, Darbyshire \& Vollesen (2007) at that time only made the necessary new combinations for species known to occur in the Flora of Tropical East Africa and Flora Zambesiaca regions. During final preparation of the latter Flora account, one of the authors (I. D.) uncovered two specimens of Peristrophe cernua Nees from southern Mozambique at the LISCand LMA herbaria. This represented a new record for the Flora Zambesiaca region and so that species was included in the Flora under the proposed new combination Dicliptera cernua (Nees) I. Darbysh. (Darbyshire 2015: 291). However, this overlooked the fact that the combination in Dicliptera had already been made three years earlier by Manning \& Goldblatt (2012). Darbyshire's (2015) combination is therefore superfluous.
Dicliptera cernua (Nees) J. C. Manning E Goldblatt (2012: 789); Darbyshire (2015: 291) as D. cernua (Nees) I. Darbysh. in error.

Peristrophe cernua Nees (1841: 374).

For a full synonymy for this species, see Darbyshire (2015).

Open Access This article is distributed under the terms of the Creative Commons Attribution 4.0 International License (http://creativecommons.org/ licenses/by/4.0/), which permits unrestricted use, distribution, and reproduction in any medium, provided you give appropriate credit to the original author(s) and the source, provide a link to the Creative Commons license, and indicate if changes were made.

\section{References}

Burkill, I. H. \& Clarke, C. B. (1900). Acanthaceae. In: W. T. Thiselton-Dyer (ed), Flora of Tropical Africa, Vol. 5. Reeve \& Co., London.

Darbyshire, I. (2015). Dicliptera. In: J. R. Timberlake \& E. S. Martins (eds), Flora Zambesiaca. Vol. 8 (6): 250 - 295. Royal Botanic Gardens, Kew.

\& Vollesen, K. (2007). The transfer of the genus Peristrophe to Dicliptera (Acanthaceae) with a new species described from eastern Africa. Kew Bull. 62: 119 - 128.

\& Ensermu Kelbessa. (2010). Acanthaceae (Part 2). In: H. J. Beentje (ed), Flora of Tropical East Africa. Royal Botanic Gardens, Kew.

\& __ (2015). Acanthaceae (Part 2). In: J. R. Timberlake \& E. S. Martins (eds), Flora Zambesiaca. Vol. 8 (6). Royal Botanic Gardens, Kew.

Kiel, C. A., Daniel, T. F., Darbyshire, I. \& McDade, L. A. (2017). Unraveling relationships in the morphologically diverse and taxonomically challenging "justicioid" lineage (Acanthaceae: Justicieae). Taxon 66: $645-674$.

Kunth, C. S. (1818). Nova genera et species plantarum, Vol. 2, Part 7 [quarto]. In: A. Bonpland \& A. Humboldt (eds), Voyage de Humboldt et Bonpland, 6th Partie. Botanique, Paris.

Lebrun, J.-P., Stork, A. L. \& Wüest, J. (1991). Un Justicia (Acanthaceae) nouveau de Tchad. Bull. Mus. Natl. Hist. Nat., B, Adansonia Ser. 4 12(3-4): 233 - 237.

\& _ (1997). Enumeration des plantes a fleurs d'Afrique tropicale. Vol. 4. Gamopetales: Clethraceae a Lamiaceae. Conservatoire et Jardin Botaniques de la Ville de Genève, Geneva.

Lindau, G. (1895). Acanthaceae Africanae 3. Bot. Jahrb. Syst. 22: 112 - 127. 
Manning, J. \& Goldblatt, P. (2012). Plants of the Greater Cape Floristic Region. 1: the Core Cape Flora. Strelitzia 29.

Moore, S. Le M. (1909). Alabastra Diversa. Part 18.3. New Tropical African Acanthaceae. J. Bot. 47: 293 296.

Nees von Esenbeck, C. G. (1841). Acanthaceae Africae Australioris ab Ecklonio collectae, adiectis nonnullis Dregeanis. Linnaea 15: 351 - 376.

Vollesen, K. (2006). A taxonomic revision of the genus Duosperma (Acanthaceae). Kew Bull. 61: 289 - 351.
(2008). Acanthaceae (Part 1). In: H. J. Beentje \& S. A. Ghazanfar (eds), Flora of Tropical East Africa. Royal Botanic Gardens, Kew.

(2010). Justicia. In: H. J. Beentje (ed.), Flora of Tropical East Africa, pp. 495 - 601. Royal Botanic Gardens, Kew. (2013). Acanthaceae (Part 1). In: J. R. Timberlake \& E. S. Martins (eds), Flora Zambesiaca. Vol. 8 (5). Royal Botanic Gardens, Kew.

(2015). Justicia. In: J. R. Timberlake \& E. S. Martins (eds), Flora Zambesiaca. Vol. 8 (6): 162 224. Royal Botanic Gardens, Kew. 